\title{
Higher risk of gastric cancer among immigrants to Ontario: a population-based matched cohort study with over 2 million individuals
}

\author{
Rinku Sutradhar ${ }^{1,2,3} \cdot$ Nnenna Asidianya $^{1} \cdot$ Faith Lee $^{2,4} \cdot$ Natalie Coburn ${ }^{3,5} \cdot$ Linda Rabeneck $^{3,5,6,7}$. \\ Lawrence Paszat ${ }^{2,3,5}$
}

Received: 15 August 2017 / Accepted: 10 December 2017 / Published online: 28 December 2017

(c) The International Gastric Cancer Association and The Japanese Gastric Cancer Association 2017

\begin{abstract}
Background The risk of gastric carcinoma (GC) varies around the world and between females and males. We aimed to compare the risk of GC among immigrants to Ontario, Canada, to the risk of GC in its general population.

Methods This was a retrospective population-based matched cohort study from 1991 to 2014. We identified immigrants who were first eligible for the Ontario Health Insurance Plan at age 40 years or older, and matched 5 controls by year of birth and sex. We calculated crude rates and relative rates of GC stratified by sex. We modeled GC hazard using multivariable Cox proportional hazards regression, where a time-varying coefficient was incorporated to examine changes in the association of immigrant status with GC hazard over time.

Results Among females, 415 GC cases were identified among 209,843 immigrants and 1872 among 1,049,215 controls. Among males, 596 GC cases were identified among 191,792 immigrants and 2998 among 958,960 controls. Comparing immigrants from East Asia and Pacific with the controls, the crude relative rate of GC was 1.54 for females and 1.32 for males. The adjusted hazard ratio (HR) for GC among female immigrants was 1.29 [95\% confidence interval (CI) $1.12,1.48$ ] within 10 years and $1.19(1.01,1.40)$ beyond 10 years; for males, the HR was $1.17(1.04,1.31)$ within 10 years and 1.00 $(0.87,1.15)$ beyond 10 years.

Conclusion The risk of GC among immigrants is elevated. Although high-risk immigrant populations in Ontario have been identified, further knowledge is required before a program of GC prevention that is targeted to them can be planned.
\end{abstract}

Keywords Immigrants · Matched cohort study · Gastric cancer · Cox regression model with time-varying coefficient · Relative rate

Rinku Sutradhar

rinku.sutradhar@ices.on.ca

1 Department of Biostatistics, Dalla Lana School of Public Health, University of Toronto, Toronto, Canada

2 Institute for Clinical Evaluative Sciences, G1-06 2075, Bayview Avenue, Toronto, ON M4N 3M5, Canada

3 Institute of Health Policy, Management and Evaluation, University of Toronto, Toronto, Canada

4 Department of Statistics, University of Waterloo, Waterloo, Canada

5 Sunnybrook Research Institute, Toronto, Canada

6 Prevention and Cancer Control, Cancer Care Ontario, Toronto, Canada

7 Department of Medicine, University of Toronto, Toronto, Canada

\section{Introduction}

The incidence of gastric carcinoma (GC) varies between males and females [1, 2], among individual nations and regions of the world [3, 4], and is associated with infectious [5-7], environmental [8,9], and genetic [10, 11] factors.

The incidence of GC in Canada and the United States of America has been declining for many years [12, 13], and is now lower than in many other countries, including the countries of origin of many of the immigrants arriving in Canada. The worldwide age-standardized rate per 100,000 persons for Canada in 2012 was estimated at 4.9, compared to 41.8 for Korea, 22.7 for China, 16.0 for Russia, 15.2 for Iran, and 8.4 for Poland [14]. This range of GC incidence parallels the range of estimates of the prevalence of infection by Helicobacter pylori (H. pylori): Canada $38.0 \%$ 
[95\% confidence interval (CI) 32.6-43.3\%), Korea $54.0 \%$ (50.1-57.8\%), China 55.8\% (51.8-59.9\%), Russia 78.5\% (67.1-89.9\%), Iran 59.0\% (51.5-66.5\%), and Poland 66.6\% (56.4-76.7\%) [6].

Prevalence surveys among migrants from countries with a high prevalence of $H$. pylori to countries with a lower prevalence have generally found the prevalence of infection to be similar to, or higher than, the prevalence in the country of origin [15]. Changes in the risk of GC among immigrants have been observed over time; for example, the declining risk of GC and mortality due to it among Japanese immigrants to the United States of America, and the further decline in risk among their offspring $[16,17]$. These risk reductions are consistent with a decreasing prevalence of infection and other environmental factors [18].

GC is considered to be a cancer that is potentially preventable by $H$. pylori eradication, and the mortality associated with it is potentially reducible by the early detection of precursor lesions or early-stage carcinoma [19, 20]. There is strong evidence that $H$. pylori infection can be eradicated by drug therapy [21], and modest evidence that this will reduce the occurrence of GC $[22,23]$. There is no evidence from randomized control trials that endoscopic screening programs will reduce death from GC, but there are case-control studies supporting the hypothesis of such a benefit [24]. There are no programs to detect $H$. pylori, GC precursors, or early-stage GC by any method in Ontario, Canada. To our knowledge, this is the first population-wide matched cohort study conducted at the individual level that assesses the burden of GC among recent immigrants to Ontario compared with similar non-immigrant individuals from the general population, and examines whether the GC risk changes over time since arrival, stratified by the world region of birth and country of birth of the immigrants. If certain high-risk immigrant populations can be identified in Ontario, this will serve as one of the first steps in the processs of planning a provincial program of GC prevention that targets these populations.

\section{Methods}

\section{Study population and outcome definition}

This was a retrospective matched cohort study conducted in Ontario, Canada, in which immigrants (the exposed group) were matched to nonimmigrants (the control group) and then followed over time to examine the hazard of gastric cancer. Individuals were identified as immigrants if there was a Date of Landing record in the Immigration, Refugees and Citizenship Canada Permanent Resident Database (IRCC) between July 1st 1991 and June 30th 2008 [25]. The index date for each immigrant was defined as the date of first eligibility for the Ontario Health Insurance Plan (OHIP), which is the universal health care insurance program that is essentially available to all Ontario residents. Immigrants had to be 40 years or older at the time of index to be included in the study, as determined based on the Registered Persons Database (RPDB). From the IRCC, we extracted the country of birth for every immigrant, and categorized country of birth according to a modified classification of selected World Bank regions (East Asia and Pacific; Europe and Central Asia; Latin America and Caribbean; Middle East and North Africa; South Asia; Sub-Saharan Africa) [26-28].

Each immigrant was matched to 5 controls using the RPDB. Controls had to be alive on the corresponding immigrant's index date, and by definition there could be no record of them in the IRCC database. Controls were also matched to immigrants based on calendar year of birth and sex. The index date for each control was assigned as the corresponding immigrant's index date. Time to gastric cancer (from index) was identified from the Ontario Cancer Registry (OCR). Individuals were followed to the date of diagnosis of gastric cancer, the date of last contact, death, or December 31, 2014 (whichever came first). It should be noted that since we wanted to follow each immigrant starting from their first date of OHIP eligibility, it was not possible to determine whether the immigrant had a prior gastric cancer diagnosis, as there were no medical records to look back on. As a result, and for consistency, a look-back period was not administered to determine whether the controls had a prior gastric cancer diagnosis. This study was approved by the Sunnybrook Health Sciences Centre Research Ethics Board. Datasets were linked using unique encoded identifiers and analyzed at the Institute for Clinical Evaluative Sciences (ICES).

\section{Statistical analyses}

All analyses were stratified by sex. Descriptive analyses were conducted by comparing the distribution of baseline characteristics among immigrants and matched nonimmigrant controls. In preliminary analyses, we computed the crude relative rates of gastric cancer among immigrants against corresponding matched controls. The crude relative rate was calculated by dividing the crude gastric cancer rate (per 100,000 person-years of follow-up) among immigrants by the crude gastric cancer rate (per 100,000 person-years of follow-up) among nonimmigrants. This was done overall, and stratified by age group, world region, and country of birth.

We conducted an individual-level analysis using a multivariable Cox regression model to examine the association between immigrant status (main binary exposure) and the gastric cancer hazard (outcome). The model adjusted for age at index, and a robust sandwich variance estimation 
approach was used to account for the matched design. Note that although matching was based on age and sex, since this was a form of exposure-control matching versus case-control matching, we were able to include age as a covariate in the model. $\log -\log$ plots were used to assess if the hazard functions were proportional [29]. As it was possible for the association between immigrant status and the hazard of gastric cancer to change over time, a time-varying coefficient for immigrant status was incorporated into the regression model [30]. This was done by adding an interaction term between immigrant status (immigrant or nonimmigrant) and time, where time was categorized into two intervals: before and after 10 years post index [31]. Doing this allowed us to determine if the association between immigrant status and the gastric cancer hazard changed once the immigrants had lived in Ontario over 10 years. All regression models were re-run stratified by world region of birth. As the risk of GC may vary among countries within the same world region, all regression models were also re-run stratified by country of birth. Analyses were conducted with SAS version 9.3 (SAS
Institute, Inc., Cary, NC, USA) and R version 3.2.3 [32]. All statistical tests were two-sided, and $p$ values of less than 0.05 were considered statistically significant.

\section{Results}

All results are presented stratified by sex. A total of $1,259,058$ females and 1,150,752 males were included in the study. Among females, there were 209,843 immigrants and 1,049,215 matched nonimmigrant controls; among males, there were 191,792 immigrants and 958,960 matched nonimmigrant controls. A description of the baseline characteristics among immigrants and controls can be found in Table 1.

Table 2 presents the crude rates of gastric cancer (per 100,000 person-years) for female immigrants and matched female nonimmigrant controls, overall and stratified by age group, world region, and country of birth. Table 3 provides the same information for male immigrants and matched male
Table 1 Distribution of characteristics comparing immigrants and matched controls, stratified by sex

\begin{tabular}{|c|c|c|}
\hline & Immigrants & Controls \\
\hline \multicolumn{3}{|l|}{ Females } \\
\hline Overall count & 209,843 & $1,049,215$ \\
\hline \multicolumn{3}{|l|}{ Year of index date } \\
\hline 1991-1995 & $59,210(28.2 \%)$ & $296,050(28.2 \%)$ \\
\hline 1996-2000 & $53,063(25.3 \%)$ & $265,315(25.3 \%)$ \\
\hline 2001-2005 & $64,922(30.9 \%)$ & $324,610(30.9 \%)$ \\
\hline 2006-2008 & $32,648(15.6 \%)$ & $163,240(15.6 \%)$ \\
\hline \multicolumn{3}{|l|}{ Age (at index date) } \\
\hline 40-49 years & $97,829(46.6 \%)$ & $489,145(46.6 \%)$ \\
\hline $50-59$ years & $51,806(24.7 \%)$ & $259,030(24.7 \%)$ \\
\hline $60-69$ years & $41,029(19.6 \%)$ & $205,145(19.6 \%)$ \\
\hline 70-74 years & $10,342(4.9 \%)$ & $51,710(4.9 \%)$ \\
\hline$\geq 75$ years & $8837(4.2 \%)$ & $44,185(4.2 \%)$ \\
\hline Median follow-up time in years (IQR) & 11.93 years $(9.32$ years $)$ & 12.96 years ( 8.86 years) \\
\hline \multicolumn{3}{|l|}{ Males } \\
\hline Overall count & 191,792 & 958,960 \\
\hline \multicolumn{3}{|l|}{ Year of index date } \\
\hline 1991-1995 & $48,793(25.4 \%)$ & $243,965(25.4 \%)$ \\
\hline 1996-2000 & $51,328(26.8 \%)$ & $256,640(26.8 \%)$ \\
\hline 2001-2005 & $62,371(32.5 \%)$ & $311,855(32.5 \%)$ \\
\hline 2006-2008 & $29,300(15.3 \%)$ & $146,500(15.3 \%)$ \\
\hline \multicolumn{3}{|l|}{ Age (at index date) } \\
\hline $40-49$ years & $106,112(55.3 \%)$ & $530,560(55.3 \%)$ \\
\hline $50-59$ years & $40,062(20.9 \%)$ & $200,310(20.9 \%)$ \\
\hline $60-69$ years & $31,575(16.5 \%)$ & $157,875(16.5 \%)$ \\
\hline 70-74 years & $8070(4.2 \%)$ & $40,350(4.2 \%)$ \\
\hline$\geq 75$ years & $5973(3.1 \%)$ & $29,865(3.1 \%)$ \\
\hline Median follow up time in years (IQR) & 11.48 years $(9.01$ years $)$ & 12.47 years $(8.46$ years $)$ \\
\hline
\end{tabular}

All data are given as number (\%) except for the median (IQR) data 
Table 2 Crude gastric cancer rates among females $(n=1,259,058)$, overall and stratified by age group, world region, and country of birth

\begin{tabular}{|c|c|c|c|c|c|c|c|}
\hline & Immigrants & $\begin{array}{l}\text { GC count } \\
\text { among immi- } \\
\text { grants }\end{array}$ & $\begin{array}{l}\text { Crude GC rate } \\
\text { among immigrants } \\
\text { (per 100,000 } \\
\text { person-years) }\end{array}$ & Controls & $\begin{array}{l}\text { GC count } \\
\text { among con- } \\
\text { trols }\end{array}$ & $\begin{array}{l}\text { Crude GC rate } \\
\text { among controls } \\
\text { (per 100,000 } \\
\text { person-years) }\end{array}$ & $\begin{array}{l}\text { Crude relative rate } \\
\text { of GC (immigrants } \\
\text { versus controls) }\end{array}$ \\
\hline Overall & 209,843 & 415 & 16.30 & $1,049,215$ & 1872 & 13.38 & 1.22 \\
\hline \multicolumn{8}{|l|}{ Age (at index) } \\
\hline $40-49$ & $97,829(46.6 \%)$ & 88 & 7.11 & $489,145(46.6 \%)$ & 398 & 5.97 & 1.19 \\
\hline $50-59$ & $51,806(24.7 \%)$ & 86 & 12.91 & $259,030(24.7 \%)$ & 469 & 12.90 & 1.00 \\
\hline $60-69$ & $41,029(19.6 \%)$ & 160 & 33.85 & $205,145(19.6 \%)$ & 631 & 23.12 & 1.46 \\
\hline $70-74$ & $10,342(4.9 \%)$ & 37 & 36.71 & $51,710(4.9 \%)$ & 201 & 34.17 & 1.07 \\
\hline$\geq 75$ & $8837(4.2 \%)$ & 44 & 63.28 & $44,185(4.2 \%)$ & 173 & 46.55 & 1.36 \\
\hline \multicolumn{8}{|l|}{ World region } \\
\hline $\begin{array}{l}\text { East Asia and } \\
\text { Pacific }\end{array}$ & $67,385(32.1 \%)$ & 180 & 22.09 & $33,6925(32.1 \%)$ & 659 & 14.32 & 1.54 \\
\hline $\begin{array}{l}\text { Europe and Cen- } \\
\text { tral Asia }\end{array}$ & $38,315(18.3 \%)$ & 98 & 20.19 & $191,575(18.3 \%)$ & 373 & 14.42 & 1.40 \\
\hline $\begin{array}{l}\text { Latin America } \\
\text { and Caribbean }\end{array}$ & $23,210(11.1 \%)$ & 47 & 15.80 & $116,050(11.1 \%)$ & 215 & 13.53 & 1.17 \\
\hline $\begin{array}{l}\text { Middle East and } \\
\text { North Africa }\end{array}$ & $16,222(7.7 \%)$ & 25 & 13.31 & $81,110(7.7 \%)$ & 132 & 12.85 & 1.04 \\
\hline South Asia & $52,103(24.8 \%)$ & 56 & 9.05 & $260,515(24.8 \%)$ & 404 & 12.03 & 0.75 \\
\hline $\begin{array}{l}\text { Sub-Sarahan } \\
\text { Africa }\end{array}$ & $8234(3.9 \%)$ & $<6$ & 6.09 & $41,170(3.9 \%)$ & 62 & 11.53 & 0.53 \\
\hline $\begin{array}{l}\text { Other world } \\
\text { region }\end{array}$ & $4374(2.1 \%)$ & $<6$ & 6.87 & $21,870(2.1 \%)$ & 27 & 9.48 & 0.72 \\
\hline \multicolumn{8}{|l|}{ Country of birth } \\
\hline India & $29,744(14.2 \%)$ & 22 & 6.46 & $148,720(14.2 \%)$ & 239 & 12.57 & 0.51 \\
\hline Pakistan & $7907(3.8 \%)$ & $<6$ & 5.64 & $39,535(3.8 \%)$ & 34 & 7.01 & 0.80 \\
\hline Sri Lanka & $10,256(4.9 \%)$ & 17 & 11.96 & $51,280(4.9 \%)$ & 103 & 14.38 & 0.83 \\
\hline $\begin{array}{l}\text { China/Hong } \\
\text { Kong/Taiwan }\end{array}$ & $39,886(19.0 \%)$ & 128 & 26.75 & $199,430(19.0 \%)$ & 406 & 14.59 & 1.83 \\
\hline Philippines & $16,461(7.8 \%)$ & 23 & 11.47 & $82,305(7.8 \%)$ & 157 & 14.62 & 0.78 \\
\hline Korea & $4194(2.0 \%)$ & 7 & 14.83 & $20,970(2.0 \%)$ & 17 & 6.43 & 2.31 \\
\hline Iran & $6754(3.2 \%)$ & 10 & 12.65 & $33,770(3.2 \%)$ & 52 & 12.24 & 1.03 \\
\hline Poland & $5373(2.6 \%)$ & 14 & 17.59 & $26,865(2.6 \%)$ & 49 & 11.47 & 1.53 \\
\hline Guyana & $5072(2.4 \%)$ & $<6$ & 4.24 & $25,360(2.4 \%)$ & 52 & 14.08 & 0.30 \\
\hline Jamaica & $5012(2.4 \%)$ & 20 & 29.09 & $25,060(2.4 \%)$ & 54 & 15.25 & 1.91 \\
\hline $\begin{array}{l}\text { United States of } \\
\text { America }\end{array}$ & $3906(1.9 \%)$ & $<6$ & 7.70 & $19,530(1.9 \%)$ & 22 & 8.65 & 0.89 \\
\hline Russia & $4686(2.2 \%)$ & 18 & 32.92 & $23,430(2.2 \%)$ & 38 & 13.58 & 2.42 \\
\hline United Kingdom & $3734(1.8 \%)$ & 9 & 22.23 & $18,670(1.8 \%)$ & 46 & 19.92 & 1.12 \\
\hline Ukraine & $3560(1.7 \%)$ & $<6$ & 9.35 & $17,800(1.7 \%)$ & 30 & 13.85 & 0.67 \\
\hline $\begin{array}{l}\text { Other country of } \\
\text { birth }\end{array}$ & $63,298(30.2 \%)$ & 132 & 17.06 & $316,490(30.2 \%)$ & 573 & 13.62 & 1.25 \\
\hline
\end{tabular}

nonimmigrant controls. As seen in Tables 2 and 3, majority of the female and male immigrants originated from the World Bank regions of East Asia and Pacific, South Asia, and Europe and Central Asia. Among females overall, the crude rate of gastric cancer was $22 \%$ higher among immigrants compared to controls, whereas the crude rate of gastric cancer was $9 \%$ higher among male immigrants compared to controls. The highest crude relative rates were seen in both women and men from the World Bank regions of East
Asia and Pacific and Europe and Central Asia (compared to their corresponding matched controls). On the other hand, the crude rate of gastric cancer was far lower in both male and female immigrants from India than in their matched controls.

The median age at diagnosis was similar for female immigrants and nonimmigrants, and for male immigrants and nonimmigrants; the median age across these groups ranged from 68.30 to 70.77 years of age. Among female immigrants 
Table 3 Crude gastric cancer rates among males $(n=1,150,752)$, overall and stratified by age group, world region, and country of birth

\begin{tabular}{|c|c|c|c|c|c|c|c|}
\hline & Immigrants & $\begin{array}{l}\text { GC count } \\
\text { among immi- } \\
\text { grants }\end{array}$ & $\begin{array}{l}\text { Crude GC rate } \\
\text { among immigrants } \\
\text { (per } 100,000 \\
\text { person-years) }\end{array}$ & Controls & $\begin{array}{l}\text { GC count } \\
\text { among con- } \\
\text { trols }\end{array}$ & $\begin{array}{l}\text { Crude GC rate } \\
\text { among controls } \\
\text { (per } 100,000 \\
\text { person-years) }\end{array}$ & $\begin{array}{l}\text { Crude relative rate } \\
\text { of GC (immigrants } \\
\text { versus controls) }\end{array}$ \\
\hline Overall & 191,792 & 596 & 26.66 & 958,960 & 2998 & 24.51 & 1.09 \\
\hline \multicolumn{8}{|l|}{ Age (at index) } \\
\hline $40-49$ & $106,112(55.3 \%)$ & 128 & 9.91 & $530,560(55.3 \%)$ & 779 & 11.03 & 0.90 \\
\hline $50-59$ & $40,062(20.9 \%)$ & 148 & 30.38 & $200,310(20.9 \%)$ & 746 & 28.27 & 1.07 \\
\hline $60-69$ & $31,575(16.5 \%)$ & 204 & 58.89 & $157,875(16.5 \%)$ & 1027 & 53.51 & 1.10 \\
\hline $70-74$ & $8070(4.2 \%)$ & 64 & 91.25 & $40,350(4.2 \%)$ & 276 & 69.77 & 1.31 \\
\hline$\geq 75$ & $5973(3.1 \%)$ & 52 & 130.22 & $29,865(3.1 \%)$ & 170 & 77.78 & 1.67 \\
\hline \multicolumn{8}{|l|}{ World region } \\
\hline $\begin{array}{l}\text { East Asia and } \\
\text { Pacific }\end{array}$ & $56,546(29.5 \%)$ & 253 & 38.54 & $282,730(29.5 \%)$ & 1081 & 29.29 & 1.32 \\
\hline $\begin{array}{l}\text { Europe and } \\
\text { Centra Asia }\end{array}$ & $32,489(16.9 \%)$ & 160 & 39.39 & $162,445(16.9 \%)$ & 473 & 21.82 & 1.80 \\
\hline $\begin{array}{l}\text { Latin America } \\
\text { and Caribbean }\end{array}$ & $17,474(9.1 \%)$ & 51 & 23.77 & $87,370(9.1 \%)$ & 254 & 22.30 & 1.07 \\
\hline $\begin{array}{l}\text { Middle East and } \\
\text { North Africa }\end{array}$ & $18,355(9.5 \%)$ & 41 & 20.13 & $91,775(9.5 \%)$ & 241 & 21.40 & 0.94 \\
\hline South Asia & $54,756(28.5 \%)$ & 71 & 11.39 & $273,780(28.5 \%)$ & 810 & 24.17 & 0.47 \\
\hline $\begin{array}{l}\text { Sub-Sarahan } \\
\text { Africa }\end{array}$ & $8215(4.3 \%)$ & 14 & 15.01 & $41,075(4.3 \%)$ & 99 & 19.21 & 0.78 \\
\hline $\begin{array}{l}\text { Other world } \\
\text { region }\end{array}$ & $3957(2.1 \%)$ & 6 & 15.74 & $19,785(2.1 \%)$ & 40 & 16.44 & 0.96 \\
\hline \multicolumn{8}{|l|}{ Country of birth } \\
\hline India & $30,557(15.9 \%)$ & 29 & 8.57 & $152,785(15.9 \%)$ & 505 & 27.22 & 0.31 \\
\hline Pakistan & $10,875(5.7 \%)$ & 8 & 6.70 & $54,375(5.7 \%)$ & 94 & 14.29 & 0.47 \\
\hline Sri Lanka & $8005(4.2 \%)$ & 14 & 13.21 & $40,025(4.2 \%)$ & 156 & 29.76 & 0.44 \\
\hline $\begin{array}{l}\text { China/Hong } \\
\text { Kong/Taiwan }\end{array}$ & $35,957(18.7 \%)$ & 179 & 43.44 & $179,785(18.7 \%)$ & 755 & 31.89 & 1.36 \\
\hline Philippines & $11,588(6.0 \%)$ & 25 & 18.10 & $57,940(6.0 \%)$ & 202 & 27.55 & 0.66 \\
\hline Korea & $4257(2.2 \%)$ & 24 & 49.95 & $21,285(2.2 \%)$ & 36 & 13.23 & 3.77 \\
\hline Iran & $7381(3.8 \%)$ & 18 & 21.24 & $36,905(3.8 \%)$ & 111 & 24.42 & 0.87 \\
\hline Poland & $3343(1.7 \%)$ & 27 & 53.75 & $16,715(1.7 \%)$ & 73 & 26.76 & 2.01 \\
\hline Guyana & $3601(1.9 \%)$ & $<6$ & 10.35 & $18,005(1.9 \%)$ & 56 & 22.40 & 0.46 \\
\hline Jamaica & $3496(1.8 \%)$ & 15 & 32.43 & $17,480(1.8 \%)$ & 70 & 29.92 & 1.08 \\
\hline $\begin{array}{l}\text { United States of } \\
\text { America }\end{array}$ & $3506(1.8 \%)$ & $<6$ & 14.92 & $17,530(1.8 \%)$ & 32 & 14.95 & 1.00 \\
\hline Russia & $3662(1.9 \%)$ & 14 & 33.11 & $18,310(1.9 \%)$ & 38 & 17.06 & 1.94 \\
\hline United Kingdom & $4142(2.2 \%)$ & 14 & 30.63 & $20,710(2.2 \%)$ & 52 & 20.67 & 1.48 \\
\hline Ukraine & $2864(1.5 \%)$ & 17 & 49.93 & $14,320(1.5 \%)$ & 29 & 16.64 & 3.00 \\
\hline $\begin{array}{l}\text { Other country of } \\
\text { birth }\end{array}$ & $58,558(30.5 \%)$ & 202 & 29.35 & $292,790(30.5 \%)$ & 789 & 21.05 & 1.39 \\
\hline
\end{tabular}

and nonimmigrants who had been diagnosed with gastric cancer, 13 and $19.5 \%$ had cancer of the cardia, respectively. Among male immigrants and nonimmigrants who had been diagnosed with gastric cancer, 19.5 and $38 \%$ had cancer of the cardia, respectively. Among individuals other than male nonimmigrants, a diagnosis of stomach cancer was most common (data not shown).
Results from multivariable Cox regression models, both without and with a time-varying coefficient, are presented in Table 4. Among females, immigrants had a $24 \%$ higher gastric cancer hazard compared with matched controls (adjusted HR $=1.24,95 \%$ CI 1.12-1.38), and this increased hazard was statistically significant. After breaking down this association further using a time-varying coefficient, we 
Table 4 Results from examining the association between immigrant status and gastric cancer hazard using a Cox regression model with a timevarying coefficient and adjusting for age

\begin{tabular}{|c|c|c|c|c|c|c|}
\hline \multirow[t]{2}{*}{ Variable } & \multicolumn{3}{|c|}{ Females $(n=1,259,058)$} & \multicolumn{3}{|c|}{ Males $(n=1,150,752)$} \\
\hline & $\begin{array}{l}\text { Univariate HR } \\
(95 \% \mathrm{CI})\end{array}$ & $\begin{array}{l}\text { Multivariate HR } \\
(95 \% \mathrm{CI})\end{array}$ & $\begin{array}{l}\text { Multivariate HR } \\
(95 \% \text { CI) with } \\
\text { interaction }\end{array}$ & $\begin{array}{l}\text { Univariate HR } \\
(95 \% \mathrm{CI})\end{array}$ & $\begin{array}{l}\text { Multivariate HR } \\
(95 \% \mathrm{CI})\end{array}$ & $\begin{array}{l}\text { Multivariate HR } \\
(95 \% \text { CI) with } \\
\text { interaction }\end{array}$ \\
\hline Immigrants & $\mathbf{1 . 2 3}(1.10,1.36)$ & $\mathbf{1 . 2 4}(1.12,1.38)$ & & $1.09(1.00,1.20)$ & $1.10(1.00,1.20)$ & \\
\hline $\begin{array}{l}\text { Nonimmigrant } \\
\text { controls }\end{array}$ & Reference & Reference & Reference & Reference & Reference & Reference \\
\hline \multicolumn{7}{|l|}{ Age (at index) } \\
\hline $40-49$ & Reference & Reference & Reference & Reference & Reference & Reference \\
\hline $50-59$ & $\mathbf{2 . 0 5}(1.81,2.31)$ & $\mathbf{2 . 0 5}(1.81,2.31)$ & $\mathbf{2 . 0 5}(1.81,2.31)$ & $\mathbf{2 . 6 0}(2.37,2.86)$ & $\mathbf{2 . 6 0}(2.37,2.86)$ & $\mathbf{2 . 6 0}(2.37,2.86)$ \\
\hline $60-69$ & $\mathbf{3 . 9 9}(3.57,4.47)$ & $\mathbf{4 . 0 0}(3.57,4.48)$ & $\mathbf{4 . 0 0}(3.57,4.48)$ & $\mathbf{5 . 0 9}(4.67,5.55)$ & $\mathbf{5 . 0 9}(4.67,5.55)$ & $\mathbf{5 . 0 9}(4.67,5.55)$ \\
\hline $70-74$ & $\mathbf{5 . 9 6}(5.10,6.96)$ & $\mathbf{5 . 9 7}(5.12,6.98)$ & $5.97(5.12,6.98)$ & $\mathbf{7 . 4 9}(6.61,8.48)$ & $\mathbf{7 . 4 9}(6.61,8.49)$ & $7.49(6.61,8.49)$ \\
\hline$\geq 75$ & $9.28(7.90,10.90)$ & $9.28(7.89,10.90)$ & $9.28(7.90,10.90)$ & $\mathbf{9 . 6 6}(8.33,11.20)$ & $9.66(8.33,11.20)$ & $\mathbf{9 . 6 6}(8.33,11.21)$ \\
\hline $\begin{array}{l}\text { Immi- } \\
\text { grants } \leq 10 \text { years } \\
\text { since index date }\end{array}$ & $\mathbf{1 . 2 7}(1.10,1.46)$ & & $\mathbf{1 . 2 9}(1.12,1.48)$ & $\mathbf{1 . 1 6}(1.03,1.29)$ & & $\mathbf{1 . 1 7}(1.04,1.31)$ \\
\hline $\begin{array}{l}\text { Controls } \leq 10 \text { years } \\
\text { since index date }\end{array}$ & Reference & & Reference & Reference & & Reference \\
\hline $\begin{array}{l}\text { Immi- } \\
\text { grants > } 10 \text { years } \\
\text { since index date }\end{array}$ & $1.17(0.99,1.38)$ & & $\mathbf{1 . 1 9}(1.01,1.40)$ & $1.01(0.88,1.16)$ & & $1.00(0.87,1.15)$ \\
\hline $\begin{array}{l}\text { Controls }>10 \text { years } \\
\text { since index date }\end{array}$ & Reference & & Reference & Reference & & Reference \\
\hline
\end{tabular}

Note that a bold hazard ratio indicates a significant association ( $p$ value $<0.05$ ), which can also be seen by the fact that the corresponding $95 \%$ confidence interval does not contain 1.0

found that the gastric cancer hazard was $29 \%$ higher among immigrants (adjusted HR $=1.29,95 \%$ CI 1.12-1.48) during the initial 10 years from index. After this point, the gastric cancer hazard was 19\% higher among immigrants but still statistically significant (adjusted HR $=1.19,95 \%$ CI 1.01-1.40). The findings were different for males. During the initial 10 years from index, male immigrants had a $17 \%$ higher gastric cancer hazard compared with their matched male nonimmigrant controls (adjusted HR $=1.17,95 \% \mathrm{CI}$ 1.04-1.31), but after this point, the gastric cancer hazard among immigrants was no different from that among the controls (adjusted HR $=1.00,95 \%$ CI $0.87-1.15$ ). There were also strong associations and trends between age at index and gastric cancer hazard. The hazard was significantly higher for older patients, and this trend was consistent among both females and males.

We re-ran all multivariable regression models stratified by world region of birth. Figure 1a provides the forest plot of the adjusted hazard ratios for gastric cancer (comparing immigrants against controls) among females before and after the 10 -year mark, overall and stratified by world region of birth. The same information for males is presented in Fig. 1b. As shown in Fig. 1a, female immigrants from the East Asia and Pacific world region and the Europe and Central Asia world region had significantly higher risks of gastric cancer compared to their matched female nonimmigrant controls. This risk was significantly higher both before and after the 10-year mark. The same pattern was seen among male immigrants from the Europe and Central Asia world region, as shown in Fig. 1b. However, among male immigrants from the East Asia and Pacific world region, the risk of gastric cancer was only higher during the first 10 years from index, after which the risk of gastric cancer was no longer significantly different between these immigrants and controls. On the other hand, among male immigrants from the South Asia world region, the gastric cancer hazard was significantly lower than that for their matched nonimmigrant controls, and this protective association remained consistent over time-both before and after the 10-year mark.

After re-running the multivariable regression models stratified by country of birth (data not shown), we found variation in the risk of GC among countries from the same 
world region. One of the largest hazard ratios for GC arose when comparing female immigrants from China/Hong Kong/Taiwan (located in the East Asia and Pacific world region) with their matched controls. The risk of gastric cancer among these female immigrants was 1.81 times higher during the first 10 years (95\% CI 1.38-2.37), and remained high even after 10 years had passed. On the other hand, the risk of GC was not significantly different between female immigrants from the Phillippines (also located in the East Asia and Pacific world region) and their matched controls. Among males, the largest hazard ratio for GC was seen among individuals from Korea compared with their matched controls (HR $=4.44,95 \%$ CI 2.30-8.57) within the first 10 years of immigration, after which the hazard ratio slightly decreased but remained significantly higher when compared with the controls (HR $=2.71,95 \%$ CI 1.16-6.35).

\section{Discussion}

In Ontario, Canada, among immigrants arriving at the age of 40 years or older, the risk of GC is higher than that among sex- and age-matched controls. This risk increases with advancing age at immigration and persists even 10 years after immigration among females. The level of risk among immigrants relative to controls varies depending on the world region of birth, and also varies among countries within the same world region.

This study is important, as it observed 1011 cases of GC among 401,635 immigrants with over 4.7 million person-years of follow-up, and included the application of time-to-event methods of analysis and the stratification of GC risk among immigrants from world regions and countries of birth with varying prevalences of $H$. pylori. A prior study of the risk of cancer among immigrants to Canada arriving between 1980 and 1990 had significant weaknesses, including fewer immigrants than this study despite it covering the entire nation. In that study, $90.8 \%$ of immigrants were $\leq 44$ years of age on arrival in Canada, and only 239 cases of GC were observed, so the risk could not be analyzed by world region or country of birth [33].

This study was limited in that only matching on calendar year of birth and sex was performed due to a lack of data on comorbidity and past medical history among the immigrants as well as a lack of valid information on their socioeconomic status prior to arrival. No direct evidence was available about the prevalence of $H$. pylori by age among the immigrants and controls or among the immigrants by region or country of birth. With respect to the outcome of gastric cancer, information on stage was not available in the administrative databases. We could not explore the risk of GC more than two decades after arrival because of the time periods included in the available data sources. We cannot assume that the cumulative risk of GC among immigrants arriving at ages younger than 40 years will reach levels similar to those observed in this study as they age; likewise, we cannot assume that immigrants arriving after 2009 will have similar risks.

It is unclear if the strong evidence for the effectiveness of combined antibiotic and proton pump inhibitor therapy in achieving $H$. pylori eradication, the moderate evidence for its ability to prevent GC, or the moderate evidence that endoscopic screening reduces GC mortality can be applied in interventions offered to asymptomatic immigrants in Ontario from high-risk regions and countries of birth. Although Japan and Korea have adopted such programs, a consensus to act on the evidence has not developed elsewhere, for a variety of reasons [34]. Testing for H. pylori, and its eradication by drug therapy, would have to be offered at younger ages (prior to irreversible changes in the gastric mucosa along the carcinogenic pathway) [35] than are appropriate for endoscopic screening, and would require valid confirmation of eradication for each treated individual, as well as surveillance of the relative sensitivity of $H$. pylori to particular antibiotics among high-risk immigrant populations in Ontario. Economic evaluations in other jurisdictions have described acceptable cost-effectiveness for $H$. pylori eradication but with variable conclusions regarding endoscopic screening for the early detection and treatment of GC precursors and GC [35-38]. Canadian economic evaluations have generally been limited to the detection and treatment of $H$. pylori in the context of dyspepsia rather than as cancer prevention strategy [39-41], with only one exception [42], which found that the incremental cost-effectiveness ratio for $H$. pylori eradication to prevent $\mathrm{GC}$ varied between $\$ 30,000$ and $\$ 50,000$ (CAD), depending on the method used for $H$. pylori detection. Further epidemiological and economic investigations would be required for a gastric cancer prevention program among high-risk immigrant groups in Ontario to become public policy.

\section{Conclusion}

GC risk is higher among immigrants in Ontario than among nonimmigrant controls, and varies with age at arrival as well as region and country of birth. High-risk immigrant populations in Ontario have been identified, but further knowledge 
a

Region of Origin (among females)

Overall

East Asia and Pacific

Europe and Central Asia

Latin America and the Caribbean

Middle East and North Africa

South Asia

Sub-Saharan Africa

b

Region of Origin (among males)

Overall

East Asia and Pacific

Europe and Central Asia

Latin America and the Caribbean

Middle East and North Africa

South Asia

Sub-Saharan Africa
Adjusted HR (95\% Cl)
Less than 10 years

$1.29(1.12-1.48)$

$1.57(1.25-1.97)$

$1.35(1.01-1.81)$

$1.05(0.67-1.64)$

$1.25(0.76-2.07)$

$1.06(0.77-1.47)$

$0.95(0.36-2.45)$

Adjusted HR (95\% Cl)

\section{Less than 10 years}

$1.17(1.04-1.31)$

$1.48(1.24-1.77)$

$1.83(1.45-2.31)$

$1.31(0.90-1.91)$

$0.92(0.60-1.41)$

$0.49(0.36-0.67)$

$0.67(0.32-1.40)$
More than 10 years

$1.19(1.01-1.40)$

$1.60(1.26-2.04)$

$1.49(1.05-2.10)$

$1.41(0.90-2.20)$

$0.69(0.30-1.62)$

$0.42(0.24-0.74)$

$0.17(0.02-1.22)$

More than 10 years

$1.00(0.87-1.15)$

$1.15(0.93-1.43)$

$1.78(1.35-2.35)$

$0.81(0.49-1.35)$

$0.97(0.57-1.65)$

$0.46(0.31-0.68)$

$0.96(0.40-2.28)$

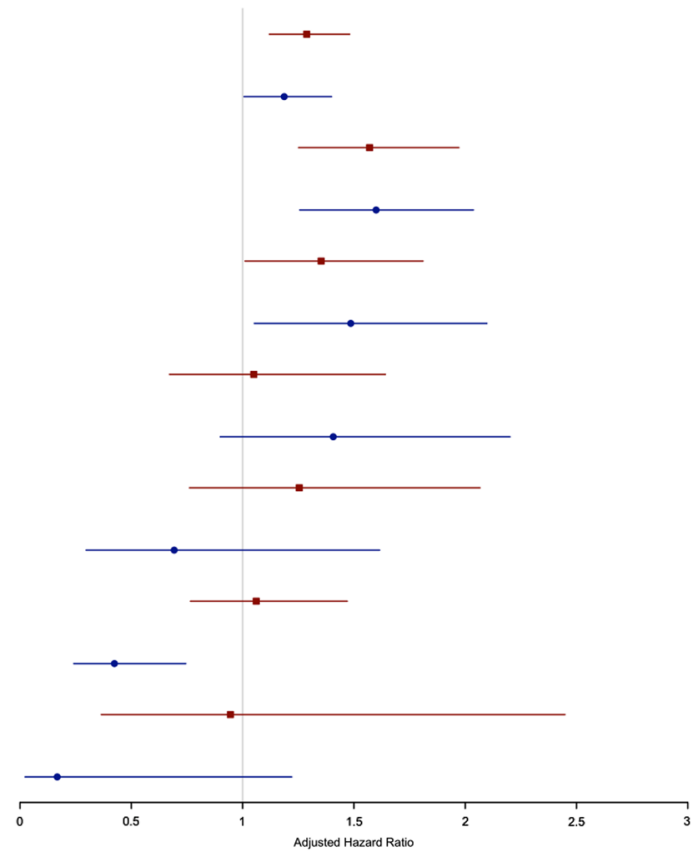

Less than 10 years

- More than 10 years
Less than 10 years

- More than 10 years 
\Fig. 1 a Forest plot of adjusted hazard ratios for gastric cancer (comparing immigrants with controls) among females before and after the 10-year mark, overall and stratified by world region of birth. Note that a bold hazard ratio indicates a significant association ( $p$ value $<0.05$ ), which can also be seen by the fact that the corresponding $95 \%$ confidence interval does not contain 1.0. b Forest plot of adjusted hazard ratios for gastric cancer (comparing immigrants with controls) among males before and after the 10-year mark, overall and stratified by world region of birth. Note that a bold hazard ratio indicates a significant association ( $p$ value $<0.05$ ), which can also be seen by the fact that the corresponding $95 \%$ confidence interval does not contain 1.0

is required before a program of gastric cancer prevention targeted to them can be planned.

Acknowledgements This study was conducted with the support of Cancer Care Ontario through funding provided by the Government of Ontario. It was supported by the Institute for Clinical Evaluative Sciences (ICES), which is funded by an annual grant from the Ontario Ministry of Health and Long-Term Care (MOHLTC). The opinions, results, and conclusions reported in this paper are those of the authors and are independent from the funding sources. Parts of this material are based on data and information provided by Cancer Care Ontario (CCO). The opinions, results, views, and conclusions reported in this paper are those of the authors and do not necessarily reflect those of CCO. No endorsement by ICES or the MOHLTC or CCO is intended or should be inferred.

Author contribution statement All of the authors had roles in the design and conduct of the study. RS, NA, and FL planned and executed the statistical analyses. All of the authors had roles in the interpretation of the results, as well as the preparation and approval of the article.

\section{Compliance with ethical standards}

Conflict of interest We declare that we have no conflict of interest.

Ethical standards This study was approved by the Sunnybrook Health Sciences Centre Research Ethics Board.

\section{References}

1. Freedman ND, Derakhshan MH, Abnet CC, Schatzkin A, Hollenbeck AR, McColl KEL. Male predominance of upper gastrointestinal adenocarcinoma cannot be explained by differences in tobacco smoking in men versus women. Eur J Cancer. 2010;46:2473-8.

2. Camargo MC, Goto Y, Zabaleta J, Morgan DR, Correa P, Rabkin CS. Sex hormones, hormonal interventions, and gastric cancer risk: a meta-analysis. Cancer Epidemiol Biomark Prev. 2012;21:20-38.

3. Ang TL, Fock KM. Clinical epidemiology of gastric cancer. Singap Med J. 2014;55:621-8.

4. Luo G, Zhang Y, Guo P, Wang L, Huang Y, Li K. Global patterns and trends in stomach cancer incidence: age, period and birth cohort analysis. Int J Cancer. 2017;141:1333-44. https:// doi.org/10.1002/ijc.30835.

5. Plummer M, Franceschi S, Vignat J, Forman D, de Martel C. Global burden of gastric cancer attributable to Helicobacter pylori. Int J Cancer. 2015; 136:487-90.
6. Hooi JK, Lai WY, Ng WK, Suen MM, Underwood FE, Tanyingoh D, et al. Global prevalence of Helicobacter pylori infection: systematic review and meta-analysis. Gastroenterology. 2017;153:420-9. https://doi.org/10.1053/j.gastro.2017.04.022.

7. Moss SF. The clinical evidence linking Helicobacter pylori to gastric cancer. Cell Mol Gastroenterol Hepatol. 2017;3:183-91.

8. Freedman ND, Abnet CC, Leitzmann MF, Mouw T, Subar AF, Hollenbeck AR, et al. A prospective study of tobacco, alcohol, and the risk of esophageal and gastric cancer subtypes. Am J Epidemiol. 2007;165:1424-33.

9. Ladeiras-Lopes R, Pereira AK, Nogueira A, Pinheiro-Torres T, Pinto I, Santos-Pereira R, et al. Smoking and gastric cancer: systematic review and meta-analysis of cohort studies. Cancer Causes Control. 2008;19:689-701

10. Chen I, Mathews-Greiner L, Li D, Abisoye-Ogunniyan A, Ray $\mathrm{S}$, Bian Y, et al. Transcriptomic profiling and quantitative highthroughput (qHTS) drug screening of CDH1 deficient hereditary diffuse gastric cancer (HDGC) cells identify treatment leads for familial gastric cancer. J Transl Med. 2017;15:92.

11. Yaghoobi M, Nabb-Baltar J, Bijarchi R, Hunt RH. What is the quantitative risk of gastric cancer in the first-degree relatives of patients? A meta-analysis. World J Gastroenterol. 2017;23:2435.

12. Howson CP, Hiyama T, Wynder EL. The decline in gastric cancer: epidemiology of an unplanned triumph. Epidemiol Rev. 1986;8:1-27.

13. Canadian Cancer Society Advisory Committee on Cancer Statistics. Canadian cancer statistics 2017. Toronto: Canadian Cancer Society. http://www.cancer.ca/ /media/cancer.ca/CW/publications/Canadian\%20Cancer\%20Statistics/Canadian-Cancer-Statistics-2017-EN.pdf. Accessed 21 Jun 2017.

14. International Agency for Research on Cancer. Global Cancer Observatory. Lyon: IARC. https://www.iarc.fr. Accessed 21 Jun 2017.

15. Morais S, Costa AR, Ferro A, Lunet N, Peleteiro B. Contemporary migration patterns in the prevalence of Helicobacter pylori infection: a systematic review. Helicobacter. 2017. https://doi. org/10.1111/hel.12372 (Epub ahead of print).

16. Haenszel W, Kurihara M. Studies of Japanese migrants. I. Mortality from cancer and other diseases among Japanese in the United States. J Natl Cancer Inst. 1968;40:43-68.

17. Shimizu H, Mack TM, Ross RK, Henderson BE. Cancer of the gastrointestinal tract among japanese and white immigrants in Los Angeles County 2. J Natl Cancer Inst. 1987;78:223-8.

18. Loffeld RJ, Van Der Putten AB. Changes in prevalence of Helicobacter pylori infection in two groups of patients undergoing endoscopy and living in the same region in the Netherlands. Scand J Gastroenterol. 2003;38:938-41.

19. Karimi P, Islami F, Anandasabapathy S, Freedman ND, Kamangar F. Gastric cancer: descriptive epidemiology, risk factors, screening, and prevention. Cancer Epidemiol Biomark Prev. 2014;23:700-13.

20. Rugge M, Genta RM, Di Mario F, El-Omar EM, El-Serag HB, Fassan M, et al. Gastric cancer as preventable disease. Clin Gastroenterol Hepatol. 2017;15:1833-43. https://doi.org/10.1016/j. cgh.2017.05.023.

21. Malfertheiner P, Megraud F, O'Morain CA, Gisbert JP, Kuipers EJ, Axon AT, et al. Management of Helicobacter pylori infection: The Maastricht V/Florence Consensus Report. Gut. 2017;66:6-30.

22. Ford AC, Forman D, Hunt R, Yuan Y, Moayyedi P. Helicobacter pylori eradication for the prevention of gastric neoplasia. Cochrane Database Syst Rev. 2015. https://doi.org/10.1002/14651858. CD005583.pub2.

23. Lee YC, Chiang TH, Chou CK, Tu YK, Liao WC, Wu MS, et al. Association between Helicobacter pylori eradication and gastric 
cancer incidence: a systematic review and meta-analysis. Gastroenterology. 2016;150:1113-24.

24. Hamashima C, Ogoshi K, Okamoto M, Shabana M, Kishimoto T, Fukao A. A community-based, case-control study evaluating mortality reduction from gastric cancer by endoscopic screening in Japan. PLoS One. 2013;8:e79088.

25. Sutradhar R, Gu S, Paszat L. Multistate transitional models for measuring adherence to breast cancer screening: a populationbased longitudinal cohort study with over 2 million women. J Med Screen. 2017;24(2):75-82 (PMID 27440758).

26. Lofters AK, Hwang SW, Moineddin R, Glazier RH. Cervical cancer screening among urban immigrants by region of origin: a population-based cohort study. Prev Med. 2010;51:509-16.

27. Creatore MI, Booth GL, Manuel DG, Moineddin R, Glazier RH. Diabetes screening among immigrants. Diabetes Care. 2012;35:754-61.

28. Lofters AK, Moineddin R, Hwang SW, Glazier RH. Predictors of low cervical cancer screening among immigrant women in Ontario, Canada. BMC Womens Health. 2011;11:20.

29. Rosner B. Fundamentals of biostatistics. 6th ed. Belmont: Duxbury Press; 2006.

30. Therneau TM, Grambsch PM. Modeling survival data: extending the Cox model. New York: Springer; 2000.

31. Allison PD. Survival analysis using SAS: a practical guide. 2nd ed. Cary: SAS Institute; 1995.

32. R Development Core Team. R: a language and environment for statistical computing. Vienna: R Foundation for Statistical Computing; 2009. http://www.R-project.org. Accessed 28 July 2014.

33. McDermott S, Desmeules M, Lewis R, Gold J, Payne J, Lafrance B, Vissandjée B, Kliewer E, Mao Y. Cancer incidence among Canadian immigrants, 1980-1998: results from a national cohort study. J Immigr Minor Health. 2011;13(1):15-26.

34. Park JY, Forman D, Greenberg ER, Herrero R. Helicobacter pylori eradication in the prevention of gastric cancer: are more trials needed? Curr Oncol Rep. 2013;15:517-25.
35. Cheng HC, Wang JD, Chen WY, Chen CW, Chang SC, Sheu BS. Helicobacter pylori test-and-treat program can be cost-effective to prevent gastric cancer in Taiwanese adults: referred to the Nationwide Reimbursement Database. Helicobacter. 2015;20:114-24.

36. Areia M, Carvalho R, Cadime AT, Rocha Goncalves F, DinisRibeiro M. Screening for gastric cancer and surveillance of premalignant lesions: a systematic review of cost-effectiveness studies. Helicobacter. 2013;18:325-37.

37. Lansdorp-Vogelaar I, Sharp L. Cost-effectiveness of screening and treating Helicobacter pylori for gastric cancer prevention. Best Prac Res Clin Gastroenterol. 2013;27:933-47.

38. Schulz TR, McBryde ES, Leder K, Biggs BA. Using stool antigen to screen for Helicobacter pylori in immigrants and refugees from high prevalence countries is relatively cost effective in reducing the burden of gastric cancer and peptic ulceration. PLoS One. 2014;9:e108610.

39. Marshall JK, Armstrong D, O'Brien BJ. Test-and-treat strategies for Helicobacter pylori in uninvestigated dyspepsia: a Canadian economic analysis. Can J Gastroenterol. 2000;14:379-88.

40. Chiba N, Veldhuyzen Van Zanten SJ, Escobedo S, Grace E, Lee $\mathrm{J}$, Sinclair P, et al. Economic evaluation of Helicobacter pylori eradication in the CADET-Hp randomized controlled trial of $H$. pylori-positive primary care patients with uninvestigated dyspepsia. Aliment Pharmacol Ther. 2004;19:349-58.

41. Masucci L, Blackhouse G, Goeree R. Cost-effectiveness of the carbon-13 urea breath test for the detection of Helicobacter pylori: an economic analysis. Ont Health Technol Assess Ser. 2013;13:1-28.

42. Xie F, O'Reilly D, Ferrusi IL, Blackhouse G, Bowen JM, Tarride $\mathrm{JE}$, et al. Illustrating economic evaluation of diagnostic technologies: comparing Helicobacter pylori screening strategies in prevention of gastric cancer in Canada. J Am Coll Radiol. 2009;6:317-23. 